\title{
Genetic Divergence Analysis in Potato (Solanum tuberosum L.)
}

\author{
Nirmodh Prabha*, H.C. Nanda and Suresh Kumar Sharma \\ Department of Genetics and Plant Breeding, S.K. College of Agriculture and Research \\ Station, Kawardha, IGKV, (C.G.), India \\ *Corresponding author
}

\begin{abstract}
A B S T R A C T
An experiment with $39 \mathrm{~F}_{1} \mathrm{C}_{1}$ clonal progenies of potato was conducted under AICRPpotato in the Horticulture Research Farm of college of Agriculture, Indira Gandhi Krishi

Keywords

Potato, Genetic divergence, Cluster analysis

\section{Article Info}

Accepted: 26 January 2018 Available Online: 10 February 2018 Vishwavidalaya, Raipur, (C.G.). Analysis of variance indicated existence of large variability among the clones for all the traits. $39 \mathrm{~F}_{1} \mathrm{C}_{1}$ clonal progenies were grouped into five distinct clusters depending upon the similarities of their $\mathrm{D}^{2}$ values. Cluster III had the highest number of progenies (11), followed by cluster IV (11), cluster I (10), cluster II (6) and cluster $\mathrm{V}(1)$. Tuber weight plant $^{-1}$ (27.12) had the highest contribution towards the total divergence. The maximum intra cluster distance was recorded in cluster III, followed by cluster II, cluster IV and cluster I. The maximum inter-cluster distance was observed between cluster I and V. Genetically diverse clusters showing superior mean performance of genotypes namely, CIP 304012-2 of cluster I; CIP 304146-1 and Kufri Surya of cluster II; CIP 398203-3 of cluster III; CIP 398201-19 and CIP 398068-21 of cluster IV; Kufri Ashoka of cluster V. The progenies developed from the selected genotypes within the limits of compatibility of these clusters, may produce high magnitude of heterosis of desirable transgressive segregants, which would be rewarding in a breeding programme.
\end{abstract}

\section{Introduction}

Potato (Solanum tuberosum L.) belonging to family Solanaceae is one of the major tuber crops of the world, especially in Europe and America; and most important commercial vegetable and food crop of India, the fourth largest food-providing commodity, after maize, rice and wheat. Potato is consumed by over billions of people across the Globe of which half is used in the developing countries.

In Chhattisgarh, it is mainly cultivated in Sarguja, Raipur, Durg, Raigarh, Jaspur, Bilaspur and Bastar districts as winter season crop, while in plateau of northern hills it is being cultivated in kharif season also. But as per the climatic suitability, it can grow well in all the agro-climatic zones of Chhattisgarh under irrigated conditions as rabi crop. In the past the cultivation area for the potato has increased but there is lack of suitable cultivars for this state, therefore there it is an urgent need to evolve the potato genotypes suitable for Chhattisgarh plains.

Genetic diversity in a population is a prerequisite for an effective plant breeding programme. The importance of genetic divergence in the improvement of crop has 
been stressed in both self and cross-pollinated crops. The main goal of potato breeding is to develop potential varieties that ensure highest and stable production in a range of environments. Genetic diversity is essential to meet the diversified goals of plant breeding such as breeding for cultivation for increasing yield, wider adaptation, desirable quality, pest and disease resistance. Hence, the precise information on the nature and degree of genetic diversity helps the plant breeders while finalizing the parents for hybridization.

\section{Materials and Methods}

Thirty nine clonal progenies $\left(39 \mathrm{~F}_{1} \mathrm{C}_{1}\right)$ obtained from genetic stock of AICRP on potato, Department of Genetics and Plant Breeding, COA, IGKV, Raipur (C.G.) were evaluated using Completely Randomized Block Design with three replications at Horticulture Research Farm of college of Agriculture, Indira Gandhi Krishi vishwavidalaya, Raipur, (C.G.) during rabi 2008-09. Each progeny was accommodated in two rows of $1 \mathrm{~m}$ length. The row to row spacing of $60 \mathrm{~cm}$ and plant to plant spacing of $20 \mathrm{~cm}$ was adopted. The recommended packages of practices were followed for twelve traits were recorded on five randomly selected plants of each progeny and yield contributing traits like Plant emergence (\%), Plant height $(\mathrm{cm})$, Number of leaves plant $^{-1}$, Number of branches plant ${ }^{-1}$, Number of shoots plant $^{-1}$, Dry matter content of shoots (\%), Dry matter content of tubers (\%), Number of tubers plant ${ }^{-1}$, Tuber weight plant $^{-1}(\mathrm{~kg})$, Marketable tuber yield plant $^{-1}(\mathrm{~kg})$, Unmarketable tuber yield plant $^{-1}(\mathrm{~kg})$ and Number of eyes tuber $^{-1}$. The multivariate analysis $\left(\mathrm{D}^{2}\right.$ statistic) was carried out following to Mahalanobis (1936). Grouping of genotypes into different clusters was carried out following Tocher's procedure (Rao, 1952) and the relative contribution of different characters towards total divergence was calculated as per Singh and Choudhary (1985).

\section{Results and Discussion}

The analysis of variance indicated significant variation among the 39 potato progenies for each of twelve characters. This suggested that large variability existed among the genotypes and the analysis of genetic divergence is reasonable. On the basis of $\mathrm{D}^{2}$ analysis, 39 $\mathrm{F}_{1} \mathrm{C}_{1}$ clonal progenies were grouped into five clusters (Table 1). The highest number of progenies appeared in cluster III and IV which possessed 11 progenies in each followed by cluster I (10), cluster II (6) and cluster V (1).

The estimates of intra and inter cluster distances represented by $\mathrm{D}^{2}$ values have been given in Table 2. The maximum intra cluster distance was recorded for cluster III (2.920), followed by cluster II (2.655), cluster IV (2.269) and cluster I (1.982). The minimum intra-cluster $\mathrm{D}^{2}$ value $(0.000)$ was recorded in case of cluster $\mathrm{V}$, which was represented by only one entry.

The highest inter-cluster distance was observed between cluster I and V (10.881) followed by cluster II and V (9.861). The inter-cluster $\mathrm{D}^{2}$ values between cluster III and V (9.716), cluster IV and V (9.668) were also very high. The lowest inter - cluster $\mathrm{D}^{2}$ values were followed between cluster II and IV (2.822) followed by cluster III and IV (2.476).

\section{Diagonal bold values indicate intra cluster distances}

The intra-cluster group means for 12 characters given in Table 3 revealed, marked differences between five clusters in respect of cluster means for different characters. Cluster II, which had six genotypes gave the highest plant emergence $(90.0 \%)$. For plant height, the highest cluster mean value was observed in 
case of cluster IV $(45.45 \mathrm{~cm})$ followed by cluster III $(40.18 \mathrm{~cm})$ and lowest in cluster I $(37.97 \mathrm{~cm})$. The highest mean value for number of leaves plant ${ }^{-1}$ was observed in case of cluster V (73.13) followed by cluster II (32.67) whereas, cluster III (27.45) showed lowest cluster mean values.

For number of branches, the highest cluster mean value was observed in cluster V (29.53) and lowest in cluster I (11.99). In case of number of shoots plant ${ }^{-1}$, the highest cluster mean value was shown by cluster V (10.13) and lowest by cluster IV, (4.94). Cluster V (18.47\%) showed highest cluster mean value for dry matter content of shoots and cluster I (14.63\%) showed lowest man values. Highest and lowest dry matter content of tubers was observed in cluster II (19.27\%) and cluster III (16.39\%), respectively, while, in case of number of tubers plant ${ }^{-1}$, the highest cluster mean value was observed in cluster $\mathrm{V}$ (14.47) and lowest in cluster I (8.07). Cluster V (0.52 $\mathrm{kg}$ ) showed highest cluster mean value for tuber weight plant $^{-1}$ and cluster II $(0.29 \mathrm{~kg})$ showed lowest.

The highest and lowest clusters mean values for marketable tuber yield plant ${ }^{-1}$ was recorded in cluster V $(0.48 \mathrm{~kg})$ and cluster II $(0.25 \mathrm{~kg})$, respectively. Unmarketable tuber yield plant ${ }^{-1}$ exhibited the highest mean performance for cluster I $(0.05 \mathrm{~kg})$ and lowest for cluster IV $(0.03 \mathrm{~kg})$, whereas, the highest number of eyes tuber $^{-1}$ (13.80) and lowest (7.96) was observed in cluster V and IV, respectively.

Table.1 Clustering pattern in $\mathrm{F}_{1} \mathrm{C}_{1}$ clonal progenies of potato

\begin{tabular}{|l|l|l|l|l|} 
Cluster & $\begin{array}{l}\text { No. of genotypes } \\
\text { included }\end{array}$ & Genotypes \\
\hline I & 10 & $\begin{array}{l}\text { CIP 304012-1, CIP 304012-2, CIP 303408-9, CIP 303408-10, } \\
\text { CIP 304102-15, CIP 304102-16, CIP 304014-1, CIP 304014-2, } \\
\text { CIP 398181-18, CIP 398181-19 }\end{array}$ \\
\hline II & 6 & $\begin{array}{l}\text { CIP 304146-1, CIP 304146-2, CIP 304046-3, CIP 304124-15, } \\
\text { Kufri Pukhraj, Kufri Surya }\end{array}$ \\
\hline III & 11 & $\begin{array}{l}\text { CIP 398203-3, CIP 302431-8, CIP 303405-11, CIP 303405-13, } \\
\text { CIP 303405-15, CIP 304102-17, CIP 304124-14, CIP 303139-11, } \\
\text { CIP 303139-13, CIP 398068-19, Kufri Jawahar }\end{array}$ \\
\hline IV & 11 & $\begin{array}{l}\text { CIP 398203-2, CIP 302024-10, CIP 302024-11, CIP 302431-9, } \\
\text { CIP 398201-19, CIP 398201-20, CIP 398201-21, CIP 398201-22, } \\
\text { CIP 303139-12, CIP 398068-21, CIP 398068-22 }\end{array}$ \\
\hline $\mathbf{V}$ & 1 & Kufri Ashoka
\end{tabular}

Table.2 Inter and intra cluster distances in $\mathrm{F}_{1} \mathrm{C}_{1}$ clonal progenies of potato

\begin{tabular}{|l|l|l|l|l|l|}
\hline Cluster & I & II & III & IV & V \\
\hline I & $\mathbf{1 . 9 8 2}$ & 3.198 & 3.119 & 3.400 & 10.881 \\
\hline II & & $\mathbf{2 . 6 5 5}$ & 3.208 & 2.822 & 9.861 \\
\hline III & & $\mathbf{2 . 9 2 0}$ & 2.476 & 9.716 \\
\hline IV & & & $\mathbf{2 . 2 6 9}$ & 9.668 \\
\hline V & & & & & $\mathbf{0 . 0 0 0}$ \\
\hline
\end{tabular}


Table.3 Component of clusters for tuber yield and its components in $\mathrm{F}_{1} \mathrm{C}_{1}$ clonal progenies of potato

\begin{tabular}{|c|c|c|c|c|c|c|c|c|c|c|c|c|c|}
\hline $\begin{array}{l}\text { Cluster } \\
\text { No. }\end{array}$ & $\begin{array}{l}\text { Number of } \\
\text { genotypes } \\
\text { included }\end{array}$ & $\begin{array}{l}\text { Plant } \\
\text { emerg- } \\
\text { ence } \\
(\%)\end{array}$ & $\begin{array}{l}\text { Plant } \\
\text { height } \\
\text { (cm) }\end{array}$ & $\begin{array}{l}\text { Number } \\
\text { of } \\
\text { leaves } \\
\text { Plant }^{-1}\end{array}$ & $\begin{array}{l}\text { Number } \\
\text { of } \\
\text { branches }^{-1} \\
\text { Plant }^{-1}\end{array}$ & $\begin{array}{l}\text { Number } \\
\text { of } \\
\text { shoots } \\
\text { Plant }^{-1}\end{array}$ & $\begin{array}{l}\text { Dry } \\
\text { matter } \\
\text { content } \\
\text { of } \\
\text { shoots } \\
(\%)\end{array}$ & $\begin{array}{l}\text { Dry } \\
\text { matter } \\
\text { content } \\
\text { of } \\
\text { Tubers } \\
(\%)\end{array}$ & $\begin{array}{l}\text { Number } \\
\text { of } \\
\text { tubers } \\
\text { Plant }^{-1}\end{array}$ & $\begin{array}{l}\text { Tuber } \\
\text { weight } \\
\text { Plant }^{-1} \\
\text { (kg) }\end{array}$ & $\begin{array}{l}\text { Marketable } \\
\text { tuber yield } \\
\text { Plant }^{-1}(\mathrm{~kg})\end{array}$ & $\begin{array}{l}\text { Unmark- } \\
\text { etable } \\
\text { tuber } \\
\text { yield } \\
\text { Plant }^{-1} \\
\text { (kg) }^{\text {kg) }}\end{array}$ & $\begin{array}{l}\text { Number } \\
\text { of eyes } \\
\text { tuber }^{-1}\end{array}$ \\
\hline I & 10 & 72.33 & 37.97 & 28.06 & 11.99 & 5.11 & 14.63 & 18.26 & 8.07 & 0.31 & 0.27 & 0.05 & 8.15 \\
\hline II & 6 & 90.00 & 39.32 & 32.67 & 14.68 & 6.51 & 17.81 & 19.27 & 8.62 & 0.29 & 0.25 & 0.04 & 8.63 \\
\hline III & 11 & 80.71 & 40.18 & 27.45 & 12.48 & 5.22 & 17.58 & 16.39 & 9.99 & 0.36 & 0.31 & 0.04 & 12.37 \\
\hline IV & 11 & 86.67 & 45.45 & 29.78 & 13.48 & 4.94 & 15.59 & 19.10 & 9.75 & 0.35 & 0.32 & 0.03 & 7.96 \\
\hline$\overline{\mathbf{V}}$ & 1 & 86.67 & 39.20 & 73.13 & 29.53 & 10.13 & 18.47 & 17.57 & 14.47 & 0.52 & 0.48 & 0.04 & 13.80 \\
\hline
\end{tabular}

Table.4 Desirable genotypes for important traits of $\mathrm{F}_{1} \mathrm{C}_{1}$ clonal progenies of potato on individual clusters

\begin{tabular}{|c|c|c|c|c|c|c|}
\hline \multirow{2}{*}{$\begin{array}{l}\text { S. } \\
\text { No. }\end{array}$} & \multirow[t]{2}{*}{ Character } & \multicolumn{5}{|l|}{ Cluster } \\
\hline & & I & II & III & IV & $\mathbf{V}$ \\
\hline 1 & Plant emergence $(\%)$ & $\begin{array}{l}\text { CIP 304012-1, } \\
\text { CIP 304012-2 }\end{array}$ & $\begin{array}{l}\text { CIP 304146-1, CIP } \\
304146-3\end{array}$ & CIP 302431-8 & $\begin{array}{l}\text { CIP 398201-19, } \\
\text { CIP 398201-21 }\end{array}$ & Kufri Ashoka \\
\hline 2 & Plant height $(\mathrm{cm})$ & CIP 398181-19 & Kufri Pukhraj & CIP 398203-3 & CIP 398201-21 & Kufri Ashoka \\
\hline$\overline{3}$ & Number of leaves Plant ${ }^{-1}$ & CIP 304014-1 & Kufri Surya & $\begin{array}{l}\text { CIP 304124-14 } \\
\text { CIP 303139-11 }\end{array}$ & CIP 398201-22 & Kufri Ashoka \\
\hline 4 & Number of branches Plant ${ }^{-1}$ & $\begin{array}{l}\text { CIP 303408-10 } \\
\text { CIP 398181-19 }\end{array}$ & Kufri Pukhraj & CIP 304124-14 & CIP 398068-21 & Kufri Ashoka \\
\hline 5 & Number of shoots Plant ${ }^{-1}$ & CIP 304102-16 & Kufri Pukhraj & Kufri Jawahar & CIP 398201-20 & Kufri Ashoka \\
\hline 6 & Dry matter content of shoots (\%) & CIP 304012-2 & Kufri Pukhraj & CIP 303405-13 & CIP 302024-11 & Kufri Ashoka \\
\hline 7 & Dry matter content of Tubers (\%) & CIP 304012-2 & Kufri Surya & CIP 303405-15 & CIP 302024-10 & Kufri Ashoka \\
\hline 8 & Number of tubers Plant ${ }^{-1}$ & CIP 304012-2 & CIP 304046-3 & CIP 302431-8 & CIP 398201-21 & Kufri Ashoka \\
\hline 9 & Tuber weight Plant $^{-1}(\mathrm{~kg})$ & CIP 398181-19 & Kufri Pukhraj & CIP 398068-19 & CIP 398201-22 & Kufri Ashoka \\
\hline 10 & Marketable tuber yield Plant ${ }^{-1}(\mathrm{~kg})$ & CIP 398181-19 & Kufri Pukhraj & CIP 398068-19 & CIP 398201-22 & Kufri Ashoka \\
\hline 11 & Unmarketable tuber yield Plant $^{-1}(\mathrm{~kg})$ & CIP 303408-9 & CIP 304146-2 & CIP 398068-19 & CIP 398068-21 & Kufri Ashoka \\
\hline 12 & Number of eyes tuber ${ }^{-1}$ & CIP 304014-2 & Kufri Pukhraj & CIP 398068-19 & CIP 398203-2 & Kufri Ashoka \\
\hline
\end{tabular}


Table.5 Percentage contribution of characters towards divergence in $\mathrm{F}_{1} \mathrm{C}_{1}$ clonal progenies of potato

\begin{tabular}{|c|c|c|}
\hline S. No. & Character & Contribution by each character (\%) \\
\hline 1 & Plant emergence (\%) & 7.83 \\
\hline 2 & Plant height $(\mathrm{cm})$ & 12.82 \\
\hline 3 & Number of leaves Plant ${ }^{-1}$ & 11.20 \\
\hline 4 & Number of branches Plant ${ }^{-1}$ & 1.08 \\
\hline 5 & Number of shoots Plant ${ }^{-1}$ & 9.45 \\
\hline 6 & Dry matter content of shoots (\%) & 4.05 \\
\hline 7 & Dry matter content of Tubers $(\%)$ & 0.13 \\
\hline 8 & Number of tubers Plant ${ }^{-1}$ & 15.65 \\
\hline 9 & Tuber weight Plant $^{-1}(\mathrm{~kg})$ & 27.12 \\
\hline 10 & Marketable tuber yield Plant $^{-1}(\mathrm{~kg})$ & 5.39 \\
\hline 11 & Unmarketable tuber yield Plant $^{-1}(\mathrm{~kg})$ & 0.54 \\
\hline 12 & Number of eyes tuber ${ }^{-1}$ & 4.72 \\
\hline
\end{tabular}

The better genotypes were identified in respect of most of the characters on the basis of mean performance in the cluster (Table 4). Among them CIP 304146-1 (93.33\%) and CIP 39820119 (93.33\%) included in cluster II and cluster IV respectively, which possessed the highest plant emergence per cent. Similarly, genotype CIP 398203-3 $(56.47 \mathrm{~cm})$ of cluster III showed highest plant height. The number of leaves plant $^{-1}$ was highest in Kufri Ashoka (73.13) in cluster V. The highest mean performance of genotype Kufri Ashoka (29.53) was observed in cluster V for number of branches plant $^{-1}$. Similarly, number of shoots plant ${ }^{-1}$ in genotype Kufri Ashoka (10.13) of cluster V exhibited the highest mean value.

The highest mean performance of genotypes of dry mater content of shoots was observed in cluster III in genotype CIP 303405-13 (22.68\%). The genotype Kufri Surya (21.97\%) of cluster II possessed the highest mean value for dry matter content of tubers. For the character, number of tubers plant ${ }^{-1}$, the highest mean value was exhibited by the genotype Kufri Ashoka (14.47) in cluster V. The highest mean for tuber weight plant $^{-1}$ was recorded in genotype Kufri Ashoka ( $0.52 \mathrm{~kg}$ ) of cluster V. The genotype Kufri Ashoka (0.48 kg) included in cluster $\mathrm{V}$ possessed the highest marketable tuber yield plant ${ }^{-1}$. The lowest mean performance of genotype CIP 398201-19 (0.012) was observed in cluster IV for unmarketable tuber yield plant ${ }^{-1}$. For character number of eyes tuber ${ }^{-1}$ the lowest mean value was exhibited by the genotype CIP 398068-21 in cluster IV and highest in genotype Kufri Ashoka in cluster V.

The per cent contribution of the characters towards total divergence of $\mathrm{F}_{1} \mathrm{C}_{1}$ clonal progenies of potato are presented in Table 5 and the data reveals that the contribution of various characters towards the total divergence was recorded for tuber weight plant $^{-1}(27.12 \%)$ followed by number of tubers plant ${ }^{-1}(15.65 \%)$, plant height (12.82\%), number of leaves plant ${ }^{-1}$ $(11.20 \%)$, number of shoots plant $^{-1}(9.45 \%)$ and plant emergence per cent $(7.83 \%)$, while, rest of the characters recorded low or negligible contribution to the total divergence.

There was a wide range of variation in cluster mean values for most of the traits. The genotypes namely, CIP 304012-2 of cluster I; CIP 304146-1 and Kufri Surya of cluster II; CIP 398203-3 and CIP 303405-13 of cluster III; CIP 398201-19 and CIP 398068-21 of cluster IV, Kufri Ashoka of cluster V are expected to give promising and desirable recombinants in segregating generations as they possess desirable features as seen from their cluster 
means. These results are in general agreement with the findings of Desai and Jaimini (1997b), Chandrakar (2007), Barik (2007), Singh (2008), Sattar et al., (2011), Panigrahi et al., (2014), and Rangare and Rangare (2017).

The per cent contribution of 12 characters towards the total divergence was recorded for tuber weight plant $^{-1}$ followed by number of tubers plant ${ }^{-1}$, plant height, number of leaves plant $^{-1}$, number of shoots plant ${ }^{-1}$ and plant emergence per cent. The similar trend and total divergence have also been reported by Joseph et al., (2005), Singh (2008), Chandrakar (2007), Barik (2007), Barik et al., (2010), and Panigrahi et al., (2014).

On the basis of inter cluster distance value, cluster $\mathrm{I}$ and $\mathrm{V}$ were identified as more divergent clusters and progenies of these clusters could be selected as parents for future hybridization programme in potato.

\section{References}

Barik SB, Verma SK, Nanda HC, Tamrakar SK. Correlation and path coefficient studies in selected genetic resources of potato (Solanum tuberosum L.) Ad. Plant Sci. 2010; 23(2):687-691.

Barik, S. B. 2007. Genetic diversity in potato (Solanum tuberosum L.)". M. Sc. (Ag.) Thesis, Indira Gandhi Krishi Vishwavidyalaya, Raipur (C.G.).

Chandrakar, A. 2007. Genetic analysis of clonal hybrids ( $\mathrm{C} 1$ progenies) for tuber yield and its components in potato (Solanum tuberosum L). M.Sc. (Ag.) Thesis, Indira Gandhi Krishi Vishwavidyalaya, Raipur (C.G.).

Desai, N. C. and Jaimini, S. N. 1997b. Studies on genetic divergence in potato (Solanum tuberosum L.). J. Indian Potato Assoc. 24 (3/4): 154-160.

Joseph TA, Birhaman R, Gopal J, Sood SK. (2005). Genetic divergence in new potato genotypes. J. Indian Potato assoc., 26:119-125.

Mahalonobis, P.C. 1936. On the generalized distance in statistics. In: Proceedings of the National Academy of Sciences (India), 2: 49-55.

Panigrahi, K.K., Sarkar, K.K., Baisakh, B. and Mohanty, A. 2014. Assessment of Genetic Divergence in Potato (Solanum tuberosum L.) Genotypes for Yield and Yield Attributing Traits. IJAEB: 7(2): 247-254.

Rangare, S.B. and Rangare, N. R. 2017. Classificatory analysis of Potato (Solanum tuberosum L.) genotypes for yield and yield attributing traits. The Pharma Innovation Journal. 6 (8): 94102.

Rao, C.R. 1952. Advanced statistical methods in biometrical research. John Wiley and Sons, New York.

Sattar, M.A., Uddin, M.Z., Islam, M.R., Bhuiyan, MKR. And Rahman, MS. (2011). Genetic Divergence in Potato (Solanum tuberosum L.). Bangladesh Journal of Agricultural Research. Vol. 36(1): 165-172.

Singh, G. 2008. Studies on genetic variability, association and divergence in potato (Solanum tuberosum L.). M.Sc. (Ag.) Thesis, Indira Gandhi Krishi Vishwavidayala, Raipur (C.G.).

Singh, R.K. and Choudhary, B.D. (1985). Biometric methods in quantitative genetic analysis- Kalyani publication, New Delhi.

\section{How to cite this article:}

Nirmodh Prabha, H.C. Nanda and Suresh Kumar Sharma. 2018. Genetic Divergence Analysis in Potato (Solanum tuberosum L.). Int.J.Curr.Microbiol.App.Sci. 7(02): 3152-3157. doi: https://doi.org/10.20546/ijcmas.2018.702.379 